\title{
Resource quality of wood waste: The importance of physical and chemical impurities in wood waste for recycling
}

\author{
Faraca, Giorgia; Boldrin, Alessio; Astrup, Thomas
}

Published in:

Waste Management

Link to article, DOI:

10.1016/j.wasman.2019.02.005

Publication date:

2019

Document Version

Peer reviewed version

Link back to DTU Orbit

Citation (APA):

Faraca, G., Boldrin, A., \& Astrup, T. (2019). Resource quality of wood waste: The importance of physical and chemical impurities in wood waste for recycling. Waste Management, 87, 135-147.

https://doi.org/10.1016/..wasman.2019.02.005

\section{General rights}

Copyright and moral rights for the publications made accessible in the public portal are retained by the authors and/or other copyright owners and it is a condition of accessing publications that users recognise and abide by the legal requirements associated with these rights.

- Users may download and print one copy of any publication from the public portal for the purpose of private study or research.

- You may not further distribute the material or use it for any profit-making activity or commercial gain

- You may freely distribute the URL identifying the publication in the public portal 
5 Resource quality of wood waste: the 6 importance of physical and chemical 7 impurities in wood waste for recycling

9

10 Giorgia Faraca*, Alessio Boldrin, Thomas Astrup

11

12 Department of Environmental Engineering, Technical University of

13 Denmark, DK-2800 Kgs. Lyngby, Denmark 


\section{Abstract}

27 Recycling of post-consumer wood waste into particleboard may be hindered 28 by the presence of physical and chemical impurities in the waste stream, 29 therefore calling for increased attention on the quality of wood waste. 30 However, wood waste comprises several uses/types of wood, along with 31 different levels of contamination. This study provides the detailed sampling 32 and characterisation of wood waste according to its source, type and resource 33 quality grade. Eight tonnes of wood waste, intended for recycling and collected 34 at three Danish recycling centres, were subdivided into 34 individual material 35 fractions and characterised with respect to the presence of three classes of 36 physical impurities (misplacements, interfering materials and low-quality 37 wood waste) as well as chemical concentrations of more than hundred chemical 38 elements and persistent organic pollutants (POPs). The results demonstrated 39 that contaminant and concentration levels vary significantly according to wood 40 waste type and source, thus emphasising that wood waste should not be viewed 41 as a single material flow but rather be understood and managed according to 42 the presence of individual fractions. Including only clean wood waste fractions 43 at the three recycling centres, $41-87 \%$ of the collected wood waste per weight 44 could be recycled - the rest being physical impurities. The results showed that 45 chemical contamination was significantly higher for low-quality wood waste, 46 thus clearly indicating that improvements in separate collection, sorting and 47 handling of wood waste may improve the resource quality of wood waste and 48 potentially achieve cleaner recycling practices.

49 Keywords: sampling; contaminant; chemical analysis; waste collection; heavy 50 metals; POPs.

\section{Abbreviations}

52 BaP: Benzo(a)pyrene; BDL: below detection limit; CCA: chromated copper 53 arsenate; C\&D: construction and demolition; EoL: End-of-Life; EPF: 54 European Panel Federation; EU: European Union; MDF: medium density 55 fibreboard; OSB: oriented strand board; PAHs: polycyclic aromatic 56 hydrocarbons; PCBs: polychlorinated biphenyls; PCP: pentachlorophenol; 57 POPs: persistent organic pollutants; RC: recycling centres; UNECE: United 58 Nations Economic Commission for Europe; WW: wood waste. 


\section{Introduction}

60 Wood represents a natural resource with specific physical and chemical 61 properties useful for a wide range of applications, for example construction, 62 furniture, packaging and energy (Parham and Gray, 1984). In 2015, the total 63 consumption of industrial roundwood in the United Nations Economic 64 Commission for Europe (UNECE) region was 1.28 billion $\mathrm{m} 3$, of which approximately $16 \%$ was used for fuel (FAO/UNECE, 2016). At end-of-life, wood waste (WW) is considered a valuable material, due to its potential for both recycling and energy recovery (Jungmeier et al., 2002a; 2002b; Sathre and Gustavsson, 2006). Historically, the main end-of-life option for wood waste has been incineration, due to its relatively high calorific value. However, wood waste may equally well be suited for a range of recycling options, potentially cascading from direct reuse (utilising the inherent material properties) to subsequent recycling in applications with lower quality standards (Reichel et al., 2016). In Europe, about 33.7 thousand $\mathrm{m} 3$ wood products became wood waste in 2010 (EPRS, 2015; Mantau et al., 2010), 46\% of which was recycled and $51 \%$ incinerated (EPRS, 2015). With increasing focus on recycling and circular economy in Europe (EC, 2018), wood waste represents an important source for secondary raw materials. The wide variety of different wood types, applications and sources makes WW a very heterogeneous material from a recycling perspective (Bergeron, 2014). As the composition and level of contamination affect recycling options, detailed information about wood waste composition is required (Vis et al., 2016). While wood waste from industry may be relatively well defined, and thus easier to recycle and utilise, wood waste generated by households and collected through municipal collection systems may be more challenging. So far, only a few attempts have been made to evaluate the quality of wood waste generated by households (see Table A.1 in the Supplementary data file for the definition of the term "quality" 87 in this study).

88 The most prominent recycling option for wood waste is particleboard (a type 89 of engineered wood-based panel), with a European production of 34.8 million $90 \mathrm{~m} 3$ in 2015 (FAO/UNECE, 2016). Amounts of recycled wood waste in 91 particleboards vary regionally: percentages range from $0 \%$ in Switzerland, to $92 \quad 15-30 \%$ in France, Spain and Germany, to 50-60\% in the UK, Belgium and 93 Denmark, and up to $100 \%$ in Italy (Humbert and Courot, 2016; Vis et al., 94 2016). Moreover, the share of wood waste usage varies also within countries 95 based on the choice of the companies manufacturing the products. Depending 
96 on the wood quality standards, additional recycling options include: wood

97 chips, pellets, refuse-derived fuel, composting, use as mulch (horticultural,

98 surfacing and soil improving mulch), animal bedding (high and standard

99 quality) and pulping into paper products (see e.g. Dodoo et al., 2014; Trada,

100 2005; Vick et al., 1996). Applications that have gained increasing focus are

101 recycling into other wood-based panels (e.g. oriented strand board, OSB, and

102 medium density fibreboard, MDF), wood composites (e.g. wood-cement and

103 wood-plastic composites) and bio-based chemicals, albeit the development of

104 these options is somewhat limited, due to technical barriers arising from low -

105 quality wood waste (Czarnecki et al., 2005; IRCOW, 2014; Winder and Bobar,

106 2016). Overall, recycling wood waste into particleboard is expected to remain

107 the primary option in the near future, also given its low price (Vis et al., 2016).

108 The quality of wood waste, however, is essential for all recycling applications

109 in terms of not only the stability and longevity of the final product (Helsen et

110 al., 1998; Vis et al., 2016), but also with respect to general concerns about

111 product quality and safety associated with recycled products (Bergeron, 2014;

112 Vis et al., 2016). Therefore, detailed information about material and chemical

113 impurities in WW is essential to ensure a high-quality, clean and safe recycling 114 loop.

115 To ensure recyclability, WW should contain minimum levels of impurities,

116 which may be defined either as physical or chemical impurities (see Table A.1

117 for definitions). In the case of WW, physical impurities are present in the form

118 of foreign materials such as plastics, metals, glass, textiles, soil, and inert

119 (concrete, bricks, tiles, stones) (Edo et al., 2015; Krook et al., 2006;

120 Värmeforsk, 2012), mostly reported as material impurities in wood waste for

121 combustion. Chemical impurities may originate primarily from treatments

122 aimed at improving product aesthetics (finishes, paints, oils, anti-stains),

123 mechanical properties (binders, adhesives, gluing agents), resistance to

124 biological decay (preservatives such as chromated copper arsenate, CCA,

125 pentachlorophenol, PCP and creosote) and resistance to fire (phosphorous and

126 brominated flame retardants) (Trada, 2005). Some of these chemicals are

127 considered hazardous only when exceeding specific limit values (e.g. heavy

128 metals), whereas other chemicals have been banned completely (e.g. CCA,

129 PCP and creosote), with associated waste being classified as 'hazardous'

130 (European Commission 1998, 2001, 2003, 2006). Concerns have been raised

131 that when impregnated WW is not handled adequately, due to improper sorting,

132 the associated chemicals may enter otherwise clean feedstocks for recycling

133 (Augustsson et al., 2016; Krook et al., 2004, 2006). Similarly, persistent 
134 organic pollutants (POPs) may be present in wood preservatives for weathering 135 resistance (e.g. phenols such as PCP), adhesives used in panelboard production 136 (e.g. polycyclic aromatic hydrocarbons - PAHs; Höglmeier et al., 2014; Vis et 137 al., 2016, Wilson, 2009) and wood floor finishes (e.g. polychlorinated 138 biphenyls - PCBs), or as a result of contamination with oils (European 139 Commission, 2006). The presence of these chemicals may potentially limit 140 recyclability in a circular economy, as they could persist in sequential 141 recycling loops (UNECE, 2010).

142 So far, the presence, types and properties of material impurities in WW 143 collected for recycling have not been addressed in the literature. On the other 144 hand, several studies have addressed the problem of chemical impurities, albeit 145 only with respect to heavy metals in WW for incineration and the consequences 146 for ash utilisation (e.g. Astrup et al., 2011, Demirbas, 2005, Edo et al., 2015), 147 despite their presence in WW for recycling may challenge a clean recycling 148 industry. Very little attention has been paid to the causes of presence of organic 149 compounds such as PAHs, phenols and PCBs in wood waste for recycling. For 150 example, despite being classified as toxic carcinogens, PAHs have been studied 151 mostly in relation to biomass combustion ashes (Edo et al., 2017, Gao et al., 152 2017, Lavric et al., 2004, Johansson and Van Bavel, 2003, Sarenbo, 2009). 153 Nevertheless, one of the most important sources of PAHs includes creosote154 treated wood (Ravindra and Sokhi, 2008), which may contaminate clean WW 155 for recycling due to improper sorting: of the approximately 150-200 chemicals 156 constituting creosote, $85 \%$ are PAHs and $10 \%$ phenolic compounds (Mueller 157 et al., 1989). Potentially, the presence and type of impurities may be associated 158 with specific sources or subtypes of wood waste; however, sufficiently detailed 159 information about the physicochemical properties of WW for recycling is not 160 available. In order to improve wood waste recycling, avoid spreading of 161 potential contaminants in material loops and enhance the quality and properties 162 of the products based on recycled wood, such data are needed.

163 The overall aim of this study is to assess to what extent the wood waste 164 composition affects the quality of recycled wood, thereby providing consistent 165 characterisation of the resource quality of wood waste recovered for recycling 166 and linking this to the source of the recovered wood waste. The focus is placed 167 on the presence of physical and chemical impurities in WW collected at Danish 168 recycling centres and then recycled into particleboard. The aim was achieved 169 by: i) sampling at three recycling centres and classifying the WW with respect 170 to material amounts, sources, application types and quality grade, ii) 171 quantifying physical (material) and chemical impurities in the WW samples, 
172 and iii) evaluating impurity levels with respect to levels in pre-consumer wood,

173 to assess the extent to which the composition of the wood differs after the use

174 phase of the products. Potential consequences of presence of impurities are

175 discussed with respect to WW recyclability and cleaner production.

\section{Materials and methods}

\section{$177 \quad 2.1$ Sampling campaign and processing of samples}

178 The sampling campaign involved three recycling centres (RCa to $\mathrm{RCc}$ ) in the

179 following Danish municipalities: Middelfart ( $\mathrm{RCa})$, Gelsted (RCb) and

180 Glamsbjerg (RCc, see Table A.1 for definitions). They were selected because

181 having identical sorting guides for WW, which is collected in separate

182 containers as 'clean wood'. Additional containers are available for

183 'impregnated wood'. Clean wood is sent for recycling as particleboard,

184 whereas impregnated wood is incinerated in authorised plants in Germany. In

185 this study, samples of WW were retrieved solely from the 'clean wood'

186 container.

187 WW sampling followed the principles set out in Boldrin and Christensen 188 (2010): one container for each recycling centre (representing $4063 \mathrm{~kg}, 1697 \mathrm{~kg}$ 189 and $2512 \mathrm{~kg}$ for $\mathrm{RCa}, \mathrm{RCb}$ and $\mathrm{RCc}$, respectively, sampled over two days and 190 corresponding to wood waste generation of about 1 week) was unloaded on the 191 ground in piles (representing primary samples of 2-4 tonnes). The WW was

192 then sorted manually into individual material fractions according to the

193 classification scheme described in Section 2.2; these fractions represented

194 secondary samples. The weights of these individual material fractions were 195 registered to determine overall material composition. All secondary samples 196 were shredded on site, using a mobile shredder (ARP SC 2000, Denmark). The

197 shredded samples were subsequently sampled through 1D lot splitting (Gy, 198 1998) to obtain seven to thirteen representative subsamples (hereafter called 199 'lab samples') of $10-15 \mathrm{~kg}$ from each of the three recycling centres (34 200 individual samples in total). These samples were stored in 30L plastic barrels 201 with a hermetic lid during transport and until further handling in the lab. Prior 202 to chemical analysis, the lab samples were processed in four steps: sorting of 203 impurities, mass reduction, size reduction, drying and storage (for further 204 details, see Appendix B). 


\subsection{Classification of wood waste}

206 While no harmonised definitions of wood waste exist (Vis et al., 2016), and

207 individual countries and sectors implement their own standards (WRAP, 208 2012a), we designed a tiered classification method addressing i) the source 209 (application) of the waste, ii) the type of item and iii) the quality grade (see 210 Table 1). The first level involves five categories: Off-cuts (O), Packaging (P), 211 Construction and demolition wood (C), Furniture (F) and Misplacements (M). 212 The second level involves a number of classes and defines further the type of 213 wood waste item, mostly focusing on the presence of fibreboard, as this type 214 of wood-based panel is currently not used in particleboard recycling (Humbert215 Droz and Coutrot, 2016). Finally, the third level represents the overall quality

216 Table 1. Tiered classification of waste wood (WW) according to (1) origin, (2) type and (3) 217 quality grade/level of contamination of the WW sample.

\begin{tabular}{|c|c|c|c|}
\hline Level 1: Origin & Level 2: Type of item & $\begin{array}{l}\text { Level 3: } \\
\text { Quality } \\
\text { grade }\end{array}$ & $\begin{array}{l}\text { Sample } \\
\text { codes }\end{array}$ \\
\hline \multirow{2}{*}{ O: Off-cuts } & $\begin{array}{l}\text { Off-cuts, left-over or large wood chips (solid wood, } \\
\text { untreated) }\end{array}$ & I, II & 01 \\
\hline & Off-cuts, with fibreboard ${ }^{\mathrm{a}}$ and/or treated wood & III & $\mathrm{O} 2$ \\
\hline \multirow{3}{*}{ P: Packaging } & Pallets, (untreated, no fibreboard) ${ }^{a}$ & I, II & P1 \\
\hline & Pallets, with fibreboard and/or treated wood & III & $\mathrm{P} 2$ \\
\hline & $\begin{array}{l}\text { Other wood packaging, clean wood (boxes, crates, } \\
\text { etc.) }\end{array}$ & I, II & P3 \\
\hline \multirow{3}{*}{$\begin{array}{l}\text { C: Construction } \\
\text { and demolition } \\
\text { (C\&D) }\end{array}$} & $\begin{array}{l}\text { Wood from C\&D and rebuilding, solid wood or with } \\
\text { engineered wood construction (no fibreboard) }{ }^{\mathrm{a}}- \\
\text { indoor use }\end{array}$ & I, II & C1 \\
\hline & $\begin{array}{l}\text { Old wood from demolition and rebuilding, with } \\
\text { fibreboard and/or treated wood, indoor use }\end{array}$ & III & $\mathrm{C} 2$ \\
\hline & $\begin{array}{l}\text { Old wood from demolition and rebuilding, with } \\
\text { fibreboard and/or treated wood, outdoor use }\end{array}$ & III & C3 \\
\hline \multirow{3}{*}{ F: Furniture } & $\begin{array}{l}\text { Furniture, solid wood or with engineered wood } \\
\text { construction (no fibreboard) }\end{array}$ & I, II & $\mathrm{F} 1$ \\
\hline & Furniture, with fibreboard and/or treated wood & III & $\mathrm{F} 2$ \\
\hline & Furniture, upholstered & III & F3 \\
\hline \multirow{4}{*}{ M: Misplacements } & $\begin{array}{l}\text { Impregnated wood (wood treated with CCA, } \\
\text { creosote or PCP) }\end{array}$ & IV & M1 \\
\hline & Composite building materials from C\&D & III & M2 \\
\hline & Wood, rotten or covered by plants & III & M3 \\
\hline & $\begin{array}{l}\text { Miscellaneous (items made out of plastic, glass, } \\
\text { metal, cardboard) }\end{array}$ & III & M4 \\
\hline
\end{tabular}

${ }^{a}$ Particleboard producers make clear technological differentiations on acceptance criteria in the recycled input stream. Fibreboard, and more specifically MDF, is the most problematic material in the input mix (due to the stability of the obtainable particleboard product) and is therefore unwanted (ARC, 2013, Humbert-Droz and Coutrot, 2016, Vis et al., 2016). 
grade of the material (I to IV) according to Altholz V (2012), Vis et al. (2016)

224 and WRAP (2012a): Grade I (clean, recyclable wood waste with minor 225 contamination), Grade II (clean wood waste with some contamination), Grade 226 III (wood waste with considerable contamination and mainly suited for 227 incineration) and Grade IV (wood waste characterised as hazardous waste 228 according to Annex III of the Waste Framework Directive2008/98/EC). Details 229 about grade definitions are provided in Table C.1. Unique sample codes (O1 to 230 M4) are assigned to all individual tiers (see Table 1).

\subsection{Wood waste characterisation: material and chemical impurities}

233 All WW samples were characterised with respect to the presence of both 234 physical (material) and chemical impurities. The material impurities were 235 categorised according to the following three types: misplacements, interfering 236 materials and low-quality wood waste. This classification, which in principle 237 is applicable to any resource collected for recycling, includes the information 238 on the material fraction of the impurity and whether it is avoidable or not, 239 besides allowing for identification of the distinct consequences caused on 240 wood waste recycling chain. Definitions and relevant sample codes are 241 provided in Table 2.

242 Table 2. Definition of impurites associated with waste wood (WW) samples.

\begin{tabular}{|c|c|c|c|c|c|}
\hline $\begin{array}{l}\text { Type of } \\
\text { impurity }\end{array}$ & Definition & $\begin{array}{l}\text { Avoida- } \\
\text { ble }\end{array}$ & $\begin{array}{l}\text { Wood is } \\
\text { the main } \\
\text { material }\end{array}$ & $\begin{array}{l}\text { Sample } \\
\text { codes }\end{array}$ & Examples \\
\hline $\begin{array}{l}\text { Misplace- } \\
\text { ments }\end{array}$ & $\begin{array}{l}\text { Items that do not match the } \\
\text { guidelines for collecting WW and } \\
\text { shall be collected separately in } \\
\text { other containers present on site } \\
\text { at the RC }\end{array}$ & Yes & Can be & $\begin{array}{l}\text { M1, M2, } \\
\text { M3, M4 }\end{array}$ & $\begin{array}{l}\text { Glass, } \\
\text { metals, } \\
\text { impregnated } \\
\text { wood, } \\
\text { cardboard, } \\
\text { bamboo }\end{array}$ \\
\hline $\begin{array}{l}\text { Interfering } \\
\text { materials }\end{array}$ & $\begin{array}{l}\text { Non-wooden items that were } \\
\text { essential during the use phase of } \\
\text { the wood waste }\end{array}$ & No & No & $\begin{array}{l}\text { Are } \\
\text { present } \\
\text { in all } \\
\text { samples }\end{array}$ & $\begin{array}{l}\text { Nails, } \\
\text { plastics } \\
\text { layers, } \\
\text { textile } \\
\text { upholstery }\end{array}$ \\
\hline $\begin{array}{l}\text { Low } \\
\text { grade } \\
\text { WW }\end{array}$ & $\begin{array}{l}\text { Wooden items whose properties } \\
\text { would lower the quality of a } \\
\text { recycled product. It is considered } \\
\text { impurities only when the purpose } \\
\text { is to achieve high-quality } \\
\text { feedstock for recycling. } \\
\text { Corresponds to quality grade III } \\
\text { in Table 1, Table C. } 1 \text { and Figure } \\
\text { H. } 1\end{array}$ & Yes & Yes & $\begin{array}{l}\mathrm{O} 2, \mathrm{P} 2, \\
\mathrm{C} 2, \mathrm{~F} 2\end{array}$ & $\begin{array}{l}\text { Panel } \\
\text { products } \\
\text { such as } \\
\text { fibreboard } \\
\text { (limited } \\
\text { potential for } \\
\text { material } \\
\text { recovery); } \\
\text { treated } \\
\text { wood }\end{array}$ \\
\hline
\end{tabular}


243 The chemical analyses included 65 inorganic chemical elements and three 244 types of organic compounds (27 PAHs, 15 phenols and 7 PCBs); see Table 245 D.1, D.2 and D.3 for further details. All analyses were performed in triplicate. 246 The method for analysing inorganic elements was adapted from available 247 literature (Edo et al., 2015, EPA, 1980, Tafur-Marinos et al., 2016). All 248 samples were measured through microwave-assisted acid digestion (Anton 249 Paar, Multiwave 3000), followed by measurements with either inductively 250 coupled plasma mass spectrometry, ICP-MS (Agilent Technologies, 7700x 251 series) or inductively coupled plasma optical emission spectrometry, ICP-OES 252 (Varian, Vista-MPX), depending on the elements and concentration levels. 253 Analysis of PAHs, phenols and PCBs was achieved by microwave-assisted 254 extraction (MAE) followed by solid-phase extraction (SPE) clean-up and 255 quantification by gas chromatography mass spectrometry (GC-MS). As the 256 methodology for analysis of PAHs and phenols was developed specifically for 257 this study (no analysis method could be found that suitably addressed these 258 classes of organic contaminants in WW), further details can be found in 259 Appendix D. While the full dataset for all 65 chemical elements is made 260 available in Appendix D, in the Results and discussion section, emphasis is 261 placed on contaminants with existing regulatory limits (see Table F.1) as well 262 as those typically associated with alloys, paints and wood preservatives, 263 namely $\mathrm{As}, \mathrm{Cd}, \mathrm{Cr}, \mathrm{Cu}, \mathrm{Pb}, \mathrm{Fe}, \mathrm{Al}, \mathrm{Mg}, \mathrm{Mn}, \mathrm{Ni}, \mathrm{Zn}, \mathrm{Co}, \mathrm{Sb}, \mathrm{Ti}, \mathrm{V}$ and $\mathrm{B}$.

264 The results from chemical analysis were compared with concentration values 265 found in:

266 i. Pre-consumer wood. Examples of different pre-consumer wood materials 267 were obtained at the retail level (e.g. hardware stores): solid wood, 268 particleboard, plywood, MDF, hardboard and impregnated wood (in total 269 seven samples, see Table E.1 for details). Characterisation and analyses 270 were identical to the WW lab samples collected from recycling centres.

271 ii. Wood waste for incineration. Data were retrieved from available scientific 272 literature.

273 iii. Virgin wood. Data were retrieved from available scientific literature as 274

275

276

277

iv. Industry standards. In the absence of European regulation defining maximum contamination levels in recycled wood, industry standards adopted by the European Panel Federation (EPF) were applied for comparison (see Table F.1 for details). 


\section{Results and discussion}

2803.1 Composition of wood waste

281 Although the overall composition (Level 1 in Table 1) of recyclable wood

282 waste collected at the three recycling centres was comparable, considerable

283 differences in the more detailed composition and shares of impurities were

284 observed, as illustrated in Figure 1a. RCa had high shares of untreated furniture

285 and C\&D waste, both clean and with low grade wood, for indoor and outdoor 286 uses (subcategories F1, C1, C2 and C3). Waste from RCb included large 287 amounts of untreated pallets, untreated $C \& D$ waste for indoor uses and 288 untreated furniture (subcategories P1, C1 and F1). RCc had high shares of 289 untreated pallets, C\&D waste for indoor and outdoor uses and untreated 290 furniture (subcategories P1, C1, C3 and F1). This indicates that the quality of 291 wood waste routed to recycling may vary significantly over time and according 292 to location.

293 Some overall trends were identified: Offcuts and Misplacements represented a 294 small share of the total WW, which was dominated mostly by C\&D and 295 Furniture alongside a smaller contribution by Packaging materials. In 296 particular, C\&D represented the largest share of WW for all recycling centres 297 (35-61\% of containers; see Figure G.1). Packaging was found in the range 5298 27\%; comparable results were found for the UK (Defra, 2012), where 299 packaging wood waste accounts for $21 \%$ of WW. Subcategories that 300 contributed very little were Off-cuts with fibreboard and/or treated wood (O2, $3011 \%$ of total wood sampled), Pallets with fibreboard and/or treated wood (P2, 302 3\%), Other packaging, untreated, no fibreboard (P3, 0.1\%), Furniture, 303 upholstered $(\mathrm{F} 3,2 \%)$ and Wood, rotten or covered by plants (M3, 1\%). The 304 largest subcategories were Furniture, untreated, no fibreboard (F1, 21\% of total 305 wood sampled), Wood from C\&D and rebuilding (untreated, no fibreboard) 306 indoor use $(\mathrm{C} 1,20 \%)$ and Old wood from demolition and rebuilding (with 307 fibreboard and/or treated) - indoor use (C2, 18\%), overall representing 59\% of 308 the total WW sampled for this study. Considering that waste management 309 constitutes the second-most important environmental impact in the building 310 sector (The Ecocycle Council for the Building Sector, 2003), and that the wood 311 fraction constitutes about 20\% of C\&D waste in Germany (European 312 Commission, 2015), 35\% in Finland (Meinander et al., 2012) and $41 \%$ in UK 313 (Defra, 2012), the compositional variations observed in this study may suggest 314 that wood waste composition should be addressed specifically when assessing 

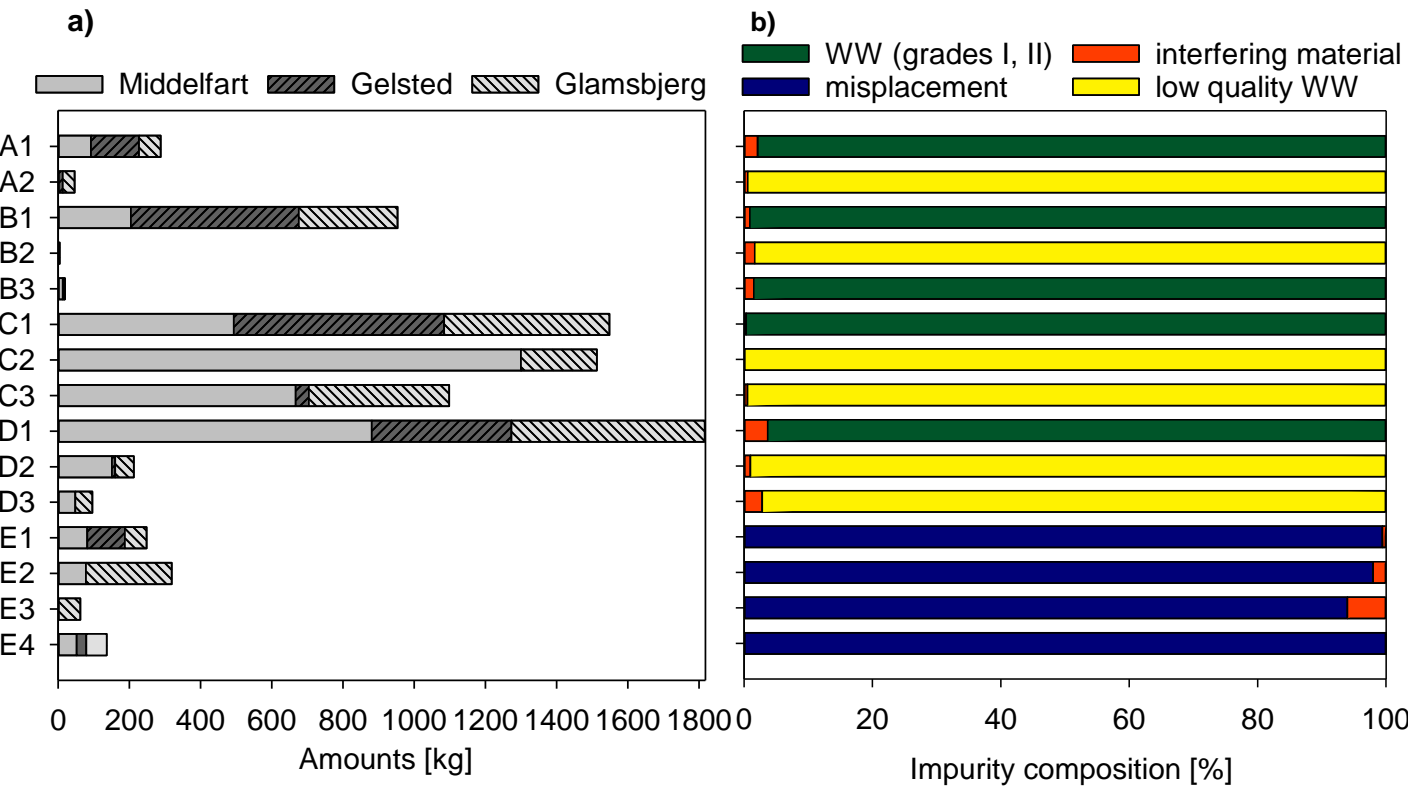

Amounts $[\mathrm{kg}]$

316 Figure 1. a) Amounts (kg, wet weight (ww)) and composition of wood waste (WW) collected 317 from the wood containers at recycling centres in the municipalities of Middelfart (RCa), 318 Gelsted (RCb) and Glamsbjerg (RCc). Original data from Econet (2016). b) Impurity 319 composition (average over three recycling centres) of sampled WW in terms of WW suitable 320 for recycling to particleboard (quality grades I and II), misplacement, interfering material 321 and low-quality WW (grade III).

322 the environmental impacts associated with the recycling and management of 323 these waste flows.

\subsection{Composition of material impurities}

325 The shares of WW that may be recycled according to the strict definition 326 (within Grades I and II) were $41 \%, 87 \%$ and $49 \%$ for $\mathrm{RCa}, \mathrm{RCb}$ and $\mathrm{RCc}$, 327 respectively (Table 3 and Figure G.2). Low-quality wood was the most 328 abundant type of impurity for $\mathrm{RCa}$ and $\mathrm{RCc}$, whereas WW from $\mathrm{RCb}$ was 329 affected mainly by presence of Misplacements. Overall, Misplacements 330 accounted for $5-17 \%$ of WW, while Interfering materials accounted for 1-2\% 331 and Low-quality wood waste for 3-53\% of the wood waste for recycling. While 332 our results showed higher levels of impurities than previously reported by Edo 333 et al. (2015) (who reported misplacements and interfering materials to 334 represent 1.1\%), a British study (WRAP, 2012b) found that 59.5\% of WW 335 collected at recycling centres was wood waste within quality Grades III and 336 IV, i.e. comparable with this study. It appeared that throughout the sampled 337 recycling centres the magnitude of the contamination of the WW depended on 338 the WW category (Figure 1b): the category Packaging was the least 339 contaminated (<5\% impurities), followed by Off-cuts and Furniture (around 
$34015 \%$ impurities). Impurities constituted $60 \%$ of C\&D WW (that represented 341 the largest share of WW), while Misplacements include impurities by 342 definition. Such conclusion is paramount as it indicates that the purity of WW 343 can be improved by knowing WW sources and limit the recycling to the 344 cleanest ones.

345 Table 3. Amounts (kg, by ww), composition and relative share (\%, by ww) of WW (grades 346 I, II), misplacement, interfering material and low-quality WW (grade III) collected at 347 Middelfart (RCa), Gelsted (RCb) and Glamsbjerg (RCc).

\begin{tabular}{|c|c|c|c|c|c|c|}
\hline & \multicolumn{2}{|c|}{ Rca - Middelfart } & \multicolumn{2}{|c|}{ RCb - Gelsted } & \multicolumn{2}{|c|}{ RCc - Glamsbjerg } \\
\hline & Kg & $\%$ & $\mathbf{k g}$ & $\%$ & $\mathrm{~kg}$ & $\%$ \\
\hline WW (grades I, II) & 1659.6 & 40.8 & 1556.7 & 87.2 & 1312.8 & 52.5 \\
\hline Misplacement & 209.8 & 5.2 & 130.9 & 7.3 & 411.1 & 16.4 \\
\hline Interfering material & 33.1 & 0.8 & 38.7 & 2.2 & 38.5 & 1.5 \\
\hline $\begin{array}{l}\text { Low-quality WW } \\
\text { (grade III) }\end{array}$ & 2160.4 & 53.2 & 58.7 & 3.3 & 738.6 & 29.5 \\
\hline Total WW & 4063.0 & 100.0 & 1785.0 & 100.0 & 2501.0 & 100.0 \\
\hline \multicolumn{7}{|l|}{ Misplacement } \\
\hline Metal & 11.0 & 5.3 & 0.9 & 0.7 & 6.4 & 1.6 \\
\hline Textile & 2.8 & 1.3 & 2.2 & 1.6 & 0.5 & 0.1 \\
\hline Plastic & 0.5 & 0.3 & 1.8 & 1.3 & 4.0 & 1.0 \\
\hline Inert & 0.0 & 0.0 & 0.9 & 0.7 & 0.9 & 0.2 \\
\hline Impregnated wood & 81.6 & 38.9 & 104.4 & 79.7 & 60.6 & 14.8 \\
\hline Composite materials & 86.2 & 41.1 & 20.3 & 15.5 & 246.2 & 59.9 \\
\hline Cardboard & 5.0 & 2.4 & 0.5 & 0.4 & 0.7 & 0.2 \\
\hline Garden waste & 22.6 & 10.8 & 0.0 & 0.0 & 33.5 & 8.2 \\
\hline Wood rotten & 0.0 & 0.0 & 0.0 & 0.0 & 58.3 & 14.2 \\
\hline Total misplacement & 209.8 & 100.0 & 130.9 & 100.0 & 411.1 & 100.0 \\
\hline \multicolumn{7}{|l|}{ Interfering material } \\
\hline Metal & 30.4 & 91.7 & 38.4 & 99.4 & 37.0 & 96.2 \\
\hline Textile & 0.1 & 0.4 & 0.0 & 0.0 & 0.3 & 0.7 \\
\hline Plastic & 2.6 & 7.8 & 0.2 & 0.6 & 1.2 & 3.1 \\
\hline $\begin{array}{l}\text { Total interfering } \\
\text { materials }\end{array}$ & 33.1 & 100.0 & 38.7 & 100.0 & 38.5 & 100.0 \\
\hline \multicolumn{7}{|c|}{ Low-quality WW (grade III) } \\
\hline Fibreboard & 1451.0 & 67.2 & 21.9 & 37.2 & 299.6 & 40.6 \\
\hline Treated/outdoor & 662.8 & 30.7 & 36.9 & 62.8 & 392.4 & 53.1 \\
\hline $\begin{array}{l}\text { Upholstered } \\
\text { furniture }\end{array}$ & 46.6 & 2.2 & 0.0 & 0.0 & 46.6 & 6.3 \\
\hline $\begin{array}{l}\text { Total low quality } \\
W W\end{array}$ & 2160.4 & 100.0 & 58.7 & 100.0 & 738.6 & 100.0 \\
\hline
\end{tabular}


348 It is evident that impurities constituted a considerable share of the WW 349 collected for recycling (12-59\%). Considering the potential competition with 350 the energy sector (wood utilisation as fuel is subsidised in the EU 351 (FAO/UNECE, 2016)) and the fact that wood waste from industry may be of 352 better quality than wood waste from recycling centres (Vis et al., 2016), the 353 presence of impurities may limit the collected wood waste from being accepted 354 for recycling (EPF, 2006). This suggests that the amount of wood waste 355 accepted at recycling facilities and eventually recycled is lower than what is 356 collected for recycling at recycling centres. Ignoring this aspect in recycling 357 statistics may result in overestimating actual recycling rates and substitution 358 of primary wood. As recycling targets are typically defined on a weight basis, 359 this may favour large and heavy waste streams rather than support the 360 separation and recovery of high-quality material fractions (Arm et al., 2016), 361 such as Grades I and II, representing 41-87\% of the sampled WW in this study. 362 When high purity is not a requirement, Low-quality WW may be recycled 363 along with Grades I and II, thereby increasing the recycling rate to $82-94 \%$ 364 (see Table 3). This clearly illustrates that recycling rates determined based on 365 waste input quantities offer little information with respect to actual resource 366 savings.

367 Although the environmental consequences of including impurities in wood 368 waste recycling activities have not been investigated to date, the effect on the 369 recycled product varies according to the class of material impurity (Table 4).

370 Potential effects on the recycling chain include increases in heavy metal 371 concentrations in recycled products, caused mainly by the presence of 372 impregnated wood and Low-quality wood waste (see also Sections 3.3, 3.4 and 373 3.5), stability and processing issues during recycling, mostly due to the content 374 of wood fibres and glue that constitute fibreboards and other wood-based 375 panels (Vis et al., 2016) and visual impurities in recycled products, which can 376 be a key factor in deciding on applications where recycled particleboard can 377 substitute its virgin counterpart (Wiebesiek, 2016). While impregnated wood 378 (Grade IV) constituted a relatively low share of the composition of WW in this 379 study (2-6\% of sampled WW), the significant presence of Low-quality wood 380 waste may require dilution with virgin wood, thereby decreasing the content of 381 recycled wood in finished products. As the use of wood-based panels grows 382 and recycling targets increase, measures to maintain high quality recycling are 383 requested in order to compete with virgin materials. 
Table 4. Overview of key types of impurities and their role in the wood waste recycling chain.

\begin{tabular}{|c|c|c|c|c|c|}
\hline $\begin{array}{l}\text { Type of } \\
\text { impurities }\end{array}$ & $\begin{array}{l}\text { Main material } \\
\text { fractions }\end{array}$ & $\begin{array}{l}\text { Potential reason } \\
\text { for their presence } \\
\text { in clean WW }\end{array}$ & $\begin{array}{l}\text { Fate of impurities at } \\
\text { the recycling facility }\end{array}$ & $\begin{array}{l}\text { Potential effects on the } \\
\text { recycling chain }\end{array}$ & Additional comments \\
\hline Misplacements & $\begin{array}{l}\text { Composite } \\
\text { materials (16- } \\
60 \%), \\
\text { impregnated wood } \\
(15-80 \%), \text { garden } \\
\text { waste }(0-11 \%)\end{array}$ & $\begin{array}{l}\text { Visual similarity } \\
\text { with clean wood } \\
\text { waste }\end{array}$ & $\begin{array}{l}\text { Hand-sorting is likely } \\
\text { to be needed, } \\
\text { although not all } \\
\text { impregnated wood } \\
\text { may be recognised }\end{array}$ & $\begin{array}{l}\text { Chemicals in impregnated } \\
\text { wood may enter new } \\
\text { products through } \\
\text { recycling }\end{array}$ & $\begin{array}{l}\text { Creosote railway sleepers } \\
\text { may be recycled if direct } \\
\text { human contact is avoided } \\
\text { (cannot be used for } \\
\text { particleboard) }{ }^{1} \text {. Low } \\
\text { concentrations of } \\
\text { impregnated wood (as in } \\
\text { this study) may be diluted }\end{array}$ \\
\hline $\begin{array}{l}\text { Interfering } \\
\text { materials }\end{array}$ & Metals (92-99\%) & $\begin{array}{l}\text { Their presence in } \\
\text { post-consumer WW } \\
\text { is unavoidable by } \\
\text { definition }\end{array}$ & $\begin{array}{l}\text { Metals are separated } \\
\text { thanks to magnetic } \\
\text { and eddy current } \\
\text { separation. Control } \\
\text { and removal of } \\
\text { plastic/textiles is } \\
\text { impossible once the } \\
\text { wood has been } \\
\text { shredded }\end{array}$ & $\begin{array}{l}\text { Visual impurities in } \\
\text { recycled products. High } \\
\text { concentration of heavy } \\
\text { metals in recycled } \\
\text { products. Advanced } \\
\text { separation technologies } \\
\text { exist but require } \\
\text { significant capital } \\
\text { investments }\end{array}$ & \\
\hline $\begin{array}{l}\text { Low quality } \\
\text { WW }\end{array}$ & $\begin{array}{l}\text { Fibreboard (37- } \\
67 \% \text { ), treated } \\
\text { wood/outdoor } \\
\text { applications (31- } \\
63 \% \text { ) }\end{array}$ & $\begin{array}{l}\text { Visual similarity } \\
\text { with solid wood } \\
\text { products. } \\
\text { Unawareness of } \\
\text { citizens }\end{array}$ & $\begin{array}{l}\text { Because WW is } \\
\text { crushed inside waste } \\
\text { containers to facilitate } \\
\text { transport, it is not } \\
\text { possible to recognise } \\
\text { and divert low-quality } \\
\text { WW }\end{array}$ & $\begin{array}{l}\text { Rejection of WW for } \\
\text { recycling. High } \\
\text { concentrations of heavy } \\
\text { metals and organic } \\
\text { compounds. Fibreboard } \\
\text { may cause stability and } \\
\text { processing problems } \\
\text { during recycling }\end{array}$ & $\begin{array}{l}\text { Although fibreboard is the } \\
\text { main cause of quality } \\
\text { downgrading (it has limited } \\
\text { potential for recovery, and } \\
\text { some facilities set limits for } \\
\text { wood-based panels at 5- } \\
10 \% \text { ), acceptance limits } \\
\text { may be given for all wood- } \\
\text { based panels }\end{array}$ \\
\hline
\end{tabular}

${ }^{1}$ (International Union of Railways, 2003). 


\subsection{Characterisation of chemical impurities: inorganic elements}

Out of the 65 analysed elements, 27 had concentrations below the detection limit (BDL) in more than $50 \%$ of cases, an overview of which is provided in Table I.1. Descriptive statistics (mean, median, min-max, quartiles) for all analysed elements are presented in Table I.2. Concentration levels of the selected elements (see Section 2.4) are plotted according to source classes in Figure 2 and Figure 3.

Packaging wood materials, mainly consisting of clean pallets (Grade I), generally had low levels of inorganic elements. Concentration levels were higher in Furniture (F), Misplacements (M) and Off-cuts (O). While this could be expected, as Misplacements included impregnated wood and Furniture included wood treated with anti-stains, paints and lacquers (Umney and Rivers, 2003) as well as non-wood materials such as textiles (see Table 1), generally Off-cuts can be expected to be cleaner. The observed levels of e.g. metals in Off-cuts may be due to i) contamination of the materials during waste collection, or ii) prior treatments of the materials. Wood waste from the C\&D sector was a heterogeneous fraction: construction timber was relatively clean, while wood from demolition appeared contaminated by coating, such as paints and preservatives (Meinander et al., 2012). The Pre-consumer wood samples (V) showed significantly smaller concentrations for all elements, except for $\mathrm{Cd}, \mathrm{Mn}$ and $\mathrm{Ti}$, where the measurements were of the same order of magnitude as the waste materials in Furniture, Misplacement, and Off-cuts.

To the extent that data have been reported in literature, the element concentrations observed here were in the same order of magnitude as indicated by other studies (Edo et al., 2015, Krook et al., 2004), although these studies addressed wood waste as feedstock for combustion rather than wood waste intended for recycling.

$\mathrm{Cd}, \mathrm{Pb}, \mathrm{Sb}, \mathrm{Co}$ and $\mathrm{Ti}$ were found in high concentrations in wood waste from $\mathrm{C} \& \mathrm{D}$ and Furniture, likely owing to the use of these elements in pigments, paints and coatings as well as lacquers for floor and furniture treatment (Fjelsted and Christensen, 2007). However, the high concentrations of $\mathrm{Pb}, \mathrm{Cd}$ and $\mathrm{Sb}$ may also originate from PVC present in C\&D wood waste, as these elements are commonly used in PVC as heat stabilisers (Mesch, 2010). Krook et al. (2006) identified surface-treatments and the presence of plastic as potential sources of $\mathrm{Pb}$ in wood waste. 

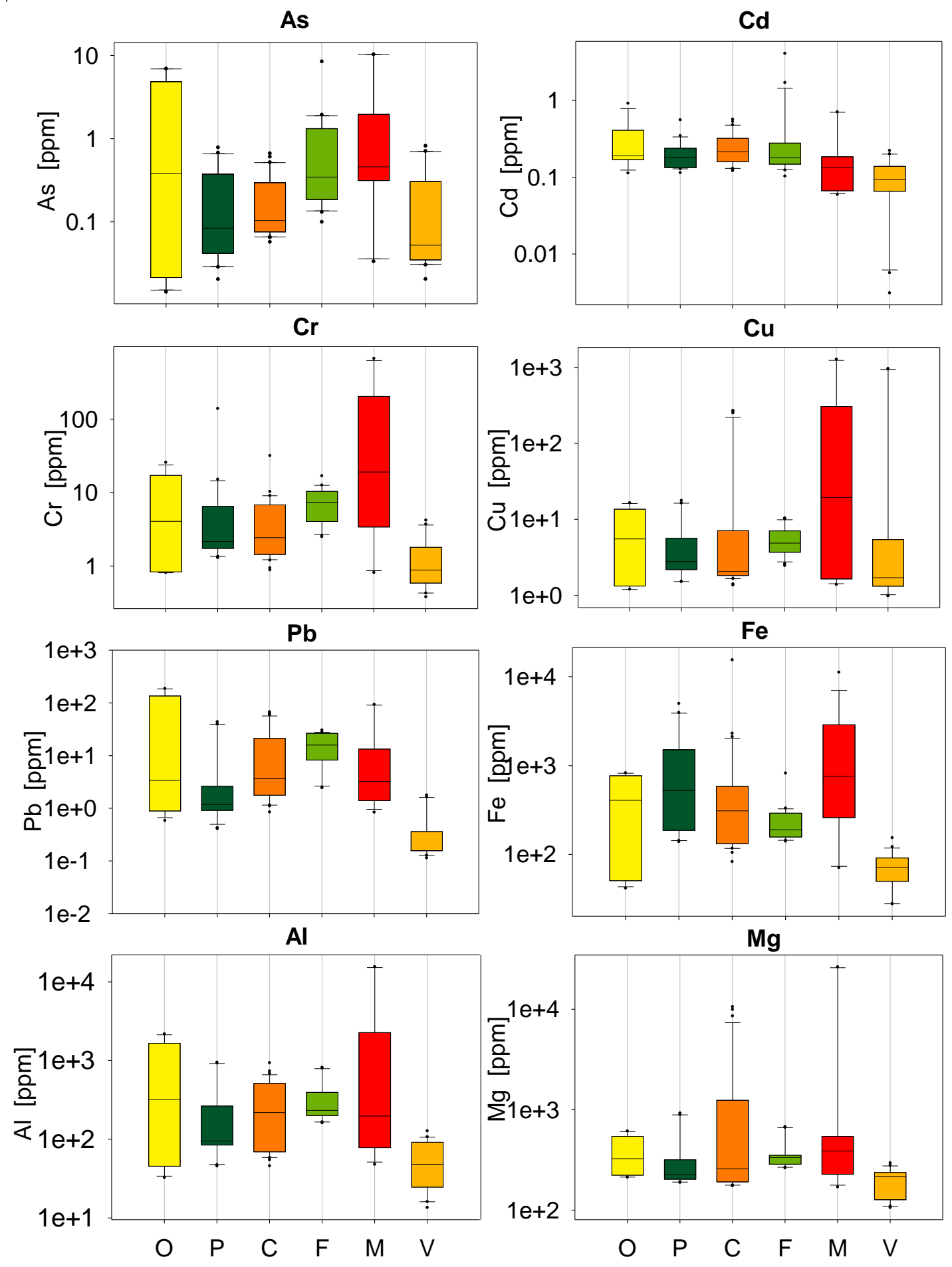

Figure 2. Concentrations (part per million, dry weight - ppm dw) of (right to left) As, Cr, $\mathrm{Cu}, \mathrm{Cd}, \mathrm{Pb}, \mathrm{Fe}, \mathrm{Al}$ and $\mathrm{Mg}$ in waste wood (WW). The grey area distinguishes results for the pre-consumer wood samples. The $\mathrm{y}$-axis is displayed using a logarithmic scale. $\mathrm{O}=\mathrm{Off}$-cuts; $\mathrm{P}=$ Packaging; $\mathrm{C}=\mathrm{C} \& \mathrm{D} ; \mathrm{F}=$ Furniture; $\mathrm{M}=$ Misplacements; $\mathrm{V}=$ Pre-consumer wood. 

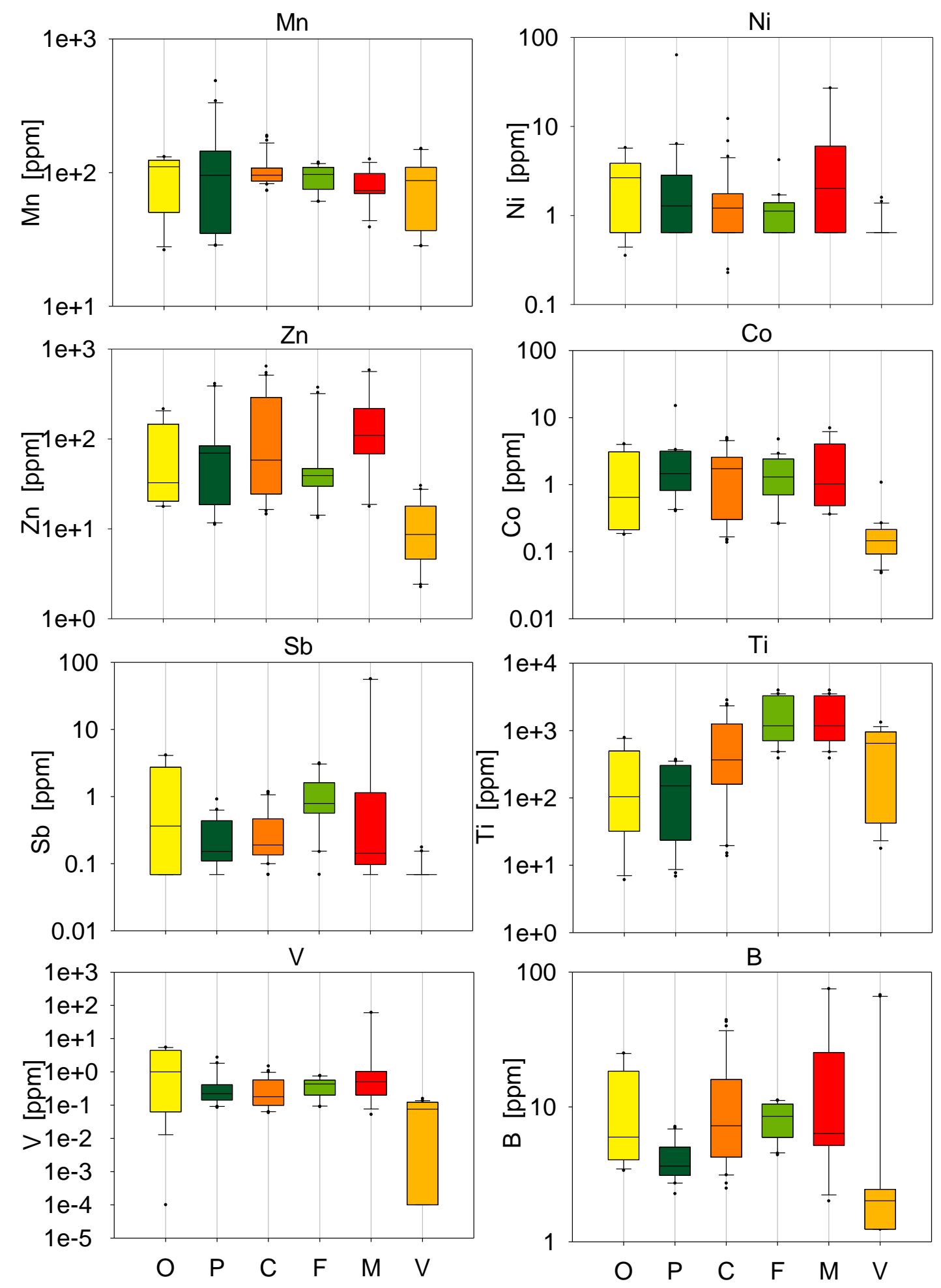

Figure 3. Concentrations (ppm dw) of (right to left) Mn, Ni, Zn, Co, Sb, Ti, V and B in waste wood (WW). The grey area distinguishes results for the pre-consumer wood samples. The $\mathrm{y}$-axis is displayed using a logarithmic scale. $\mathrm{O}=$ Off-cuts; $\mathrm{P}=$ Packaging; $\mathrm{C}=\mathrm{C} \& \mathrm{D} ; \mathrm{f}=$ Furniture; M= Misplacements; V= Pre-consumer wood. 
Although the observed levels of $\mathrm{As}, \mathrm{Cr}$ and $\mathrm{Cu}$ were lower than found in other studies (Frighetto Ferrarini et al., 2016; Johansson and Van Bavel, 2003b), the high concentrations in Misplacements (M) were likely caused by presence of impregnated wood. Table J.1 summarises the differences in concentrations of $\mathrm{As}, \mathrm{Cr}$ and $\mathrm{Cu}$ for the lab sample with the highest concentrations (M1) and values found by Frighetto Ferrarini et al. (2016) and Janin et al. (2009), who measured initial concentrations of these compounds in wood waste from Eucaliptus poles and CCA-treated Red Pine poles, respectively. The values in our study were of the same order of magnitude for $\mathrm{Cu}$, albeit one order of magnitude (for $\mathrm{Cr}$ ) and three orders of magnitude (for As) smaller than found by Frighetto Ferrarini et al. (2016) and Janin et al. (2009).

Levels of $\mathrm{Zn}$ were highest in Misplacements, possibly due to the use of $\mathrm{Zn}$ in wood preservatives such as ammoniacal copper-zinc-arsenate (ACZA) (US EPA, 1992). However, relatively high $\mathrm{Zn}$ levels were found also in Packaging, C\&D waste and Furniture, which may rather reflect the widespread use of Zn in galvanised fastening systems (Krook et al., 2006). Fe concentrations were high in all sample types, probably due to the high concentration of iron in water- and solvent-based paints, wood preservatives and lacquers (Fjelsted and Christensen, 2007) as well as migration from metals (nails, joints, etc.). Al, Ni and $\mathrm{Mg}$ levels were very high in some samples, possibly due to contamination from metallic components such as nails, joints, etc. and inert materials.

Overall, it is possible to distinguish between elements whose composition is relatively similar across the various wood waste categories (e.g. Cd, Al, Mg, $\mathrm{Mn}, \mathrm{Ni}, \mathrm{Co}, \mathrm{V}, \mathrm{B})$ and elements which are present primarily in selected categories (e.g. As, $\mathrm{Cr}, \mathrm{Cu}, \mathrm{Pb}, \mathrm{Zn}, \mathrm{Sb}, \mathrm{Ti}$ ). As the concentration levels of some of these elements (see Figures 2 and 3) varied considerably, this suggests that wood waste cannot be regarded as a homogeneous waste fraction but rather that the composition of the individual material types within wood waste have to be considered. Based on the results presented herein, it is possible to estimate contamination levels based on the source of the wood waste, thereby improving a quality-oriented selection of wood waste which is necessary in order to achieve a cleaner production. It should be noticed that the cleanest material type, namely Packaging, was present only in relatively low amounts (14\% of total WW). Compared to the Pre-consumer wood samples, WW for recycling showed significantly higher concentrations for $\mathrm{Cr}, \mathrm{Cu}, \mathrm{Pb}, \mathrm{Fe}, \mathrm{Al}$, $\mathrm{Mg}, \mathrm{Zn}$, Co, Sb, Ti and V. As these elements are generally associated with preservation $(\mathrm{Cr}, \mathrm{Cu}, \mathrm{Zn})$, painting and coating $(\mathrm{Pb}, \mathrm{Co}, \mathrm{Sb}, \mathrm{Ti}, \mathrm{Fe})$ and metals and alloys ( $\mathrm{Pb}, \mathrm{Al}, \mathrm{Mg}, \mathrm{Zn}, \mathrm{Fe}, \mathrm{V})$, the results may indicate that concentrations 
of these elements increased during the use phase, owing to the indiscriminate use of paints and treatments by consumers (while making the presence of contaminants untraceable), although it could also be caused by migration of contaminants during waste collection.

Overall, element concentrations complied with the limits defined by the EPF (EPF, 2014) for maximum limit values of selected compounds in wood-based panels containing recycled wood (see Table K.1). Although in some cases maximum values in lab samples were one (for $\mathrm{Cr}$ and $\mathrm{Pb}$ ) or two (for $\mathrm{Cu}$ ) orders of magnitude higher than the thresholds, mean values were below the limits, except for the case of $\mathrm{Cu}$, whose mean concentration was two-fold the limit value. Lab samples exceeding the EPF limits belonged predominantly to the impurity classes Misplacements (samples M1, impregnated wood) and Lowquality wood waste $(\mathrm{C} 3, \mathrm{M} 2, \mathrm{O} 2)$, confirming that the effect of the presence of impurities in wood waste for recycling is not to be underestimated.

\subsection{Characterisation of chemical impurities: organic compounds}

Most of the analysed organic compounds were BDL: while the full dataset is provided in Table L.1, the following discussion focuses on total contents. Figure 4 provides an overview of concentration levels for PCP, total sum of PAHs, total sum of phenols and total sum of PCBs.

Overall, the observed concentration levels were relatively low and never higher than $10 \mathrm{ppm}$. PCP was found mainly in furniture and misplacements. The EPF limit for PCP (5 ppm, Table K.1) was exceeded by a single sample in the Misplacement category (M1 at $9.13 \mathrm{ppm}$ ), possibly due to the use of PCP as wood preservative for outdoor applications. The total sum of phenols was within the same order of magnitude for all samples, except for Packaging wood, which had lower concentrations. Phenols may be added as phenolic or phenol-formaldehyde resins to wood during the production of engineered boards as binders and adhesives ( $\mathrm{Li}$ et al., 2016). Although the median concentrations never exceeded $1 \mathrm{ppm}$, phenols are toxic even in low concentrations and may potentially be spread to the environment during outside storage prior to recycling (US EPA, 1985).

The total sum of PAHs was observed within $10-5$ and $10+1 \mathrm{ppm}$, which is significantly lower than concentrations of $10+4 \mathrm{ppm}$ found by Löser et al. (1999) in PAH-contaminated wood waste. Total PAH levels of around $16 \mathrm{ppm}$ were reported for ashes from incinerating pure wood chips (Bundt et al., 2001) 

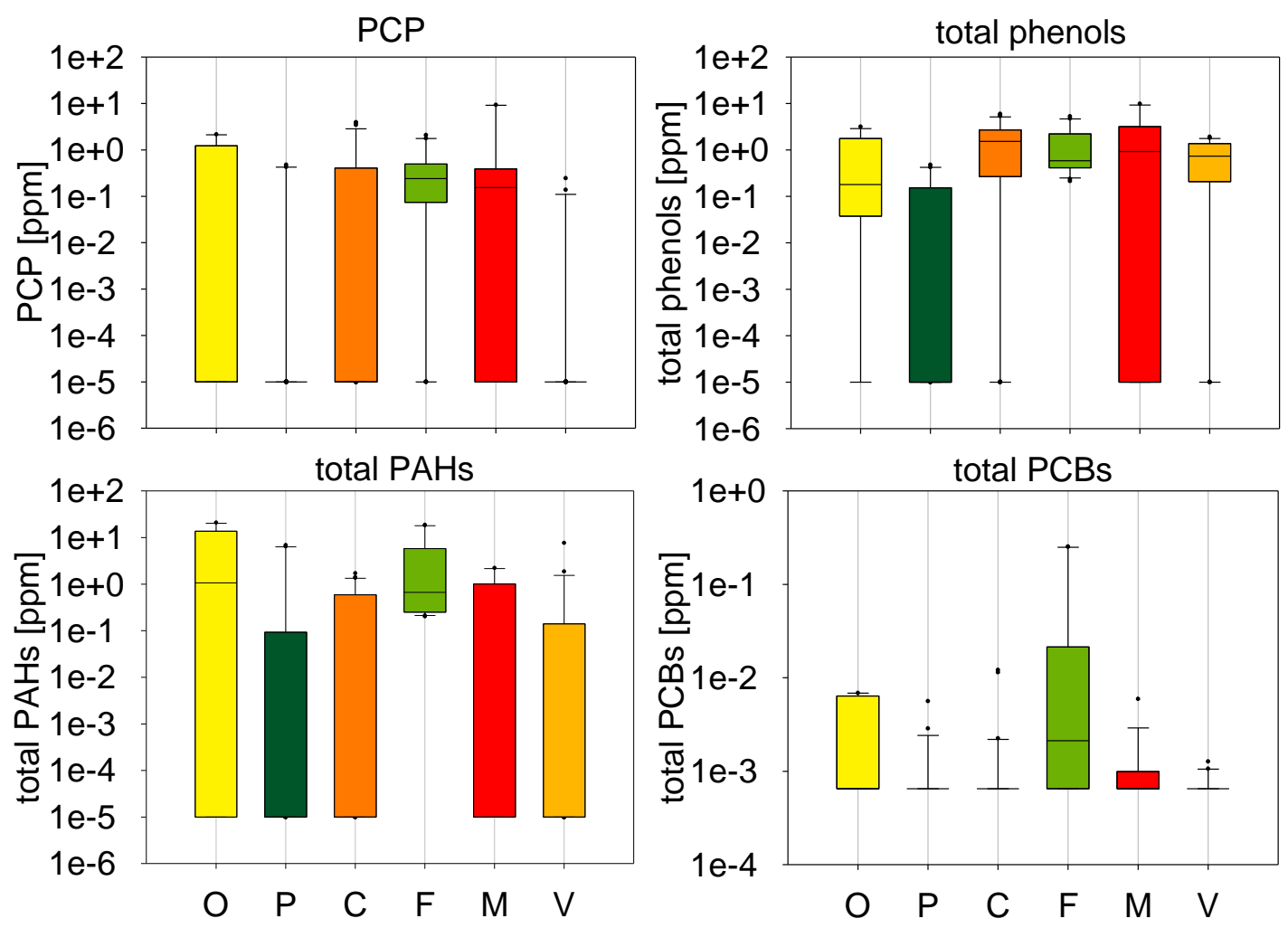

Figure 4. Concentrations (ppm dw) of (right to left) PCP, PAHs (total sum), phenols (total sum) and PCBs (total sum) in waste wood (WW) samples. The grey area distinguishes results for the pre-consumer wood samples. The y-axis is displayed using a logarithmic scale.

and in the range of 0.48-3.59 for ashes from municipal solid waste incineration (Johansson and Van Bavel, 2003b). PAH levels were found comparable in Offcuts and Furniture, whereas the other categories were lower. As an indicator for creosote (EPF, 2014), Benzo(a)pyrene (BaP) was detected only in two samples ( $\mathrm{O} 2$ and $\mathrm{F} 2)$, albeit in concentrations below the EPF limits $(0.5 \mathrm{ppm})$. While BaP levels in creosote-treated wood may have been around 20-35 ppm (Erlandsson and Almemark, 2009), the relatively lower levels observed here suggest that contamination with creosote-impregnated wood is not a major concern. Despite the low concentrations, both PAHs and phenols are classified as POPs, which preferably should be destroyed rather than recycled (UNECE, 2010). Of the three detected PAHs (BaP, benzo(b)fluoranthene and benzo(k)fluoranthene) specified as the most carcinogenic compounds by the UNECE (2010), BaP was detected at 0.10-0.24 ppm, benzo(b)fluoranthene at 0.14-0.85 ppm and benzo(k)fluoranthene at 0.09-0.54 ppm.

PCBs were not detected in most samples. The highest concentrations were observed in Furniture category, with the highest value of $0.253 \mathrm{ppm}$ in the clean furniture subgroup (sample F1). Abb et al. (2010) reported a maximum value of $0.14 \mathrm{ppm}$ total PCBs in wood waste of grades I and II, and up to 1.2 
ppm in wood waste of grades III and IV. PCBs may originate from contamination, e.g. due to stabilisers in fluorescent lights or home appliances, elastic sealants, insulating board and sound-insulating board treated with agents containing PCBs, cement and other building materials, oil used during the wood chipping process, adhesives and wood floor finishes (Herrick et al., 2004; Robson et al., 2010; Andersson et al., 2003; Rudel et al., 2008). PCBs have also been used in the past as plasticisers in paints and in flame-retardant coatings (Butera et al., 2014; Jartun et al., 2009a, b), which may potentially have caused their higher concentrations in the Furniture samples. It should be noticed that PCBs could not be extracted from samples containing cement/asphalt (sample code M2), as the sample matrix analysed by GC-MS was too complex. PCBs are (similarly to phenols and PAHs) classified as POPs and their production and utilisation is banned (UNEP, 2009). As such, recycling should be avoided, and any contamination of these compounds into products should be minimised.

\subsection{Recommendations for wood waste collection, sorting and recycling}

Figure 5 provides an overview and comparison of chemical levels in clean wood waste (Grades I, II) relative to the levels in Low quality wood waste (Grade III) and hazardous wood waste (Grade IV). The figure clearly emphasises that WW belonging to Grades III and IV contained higher concentrations for all inorganic elements and organic compounds. In some cases, concentrations were three times higher (for As, Pb, PCP, B, Al, Mg, Fe), seven times higher (for $\mathrm{Cr}, \mathrm{Sb}$ ), ten times higher (for PAHs, V) and even 26 times higher (for $\mathrm{Cu}$ ) than the values for clean WW (Grades I, II), which suggests that the separate collection and alternative disposal of Grades III and IV may dramatically decrease the level of chemicals in wood waste for recycling. Therefore, Low quality wood waste (Grade III) should be collected separately from clean WW (Grades I, II), in order to avoid unwanted contaminations of chemicals. Moreover, considering that fibreboards make up $37-67 \%$ of the composition of low-quality wood waste in this study (cfr. Table 3 ), and that fibreboard production in Europe has been rather stable at 15.5 million m3/year throughout 2007-2016 (FAO/UNECE, 2016; Wollf, 2016), it may be expected that comparable quantities will also be discarded in the near future. Nevertheless, incineration of fibreboard, as an alternative to recycling, may possibly release organic pollutants (Edo et al., 2017). For example, Gao 
et al. (2017) reported polychlorinateddibenzo-p-dioxins levels in products

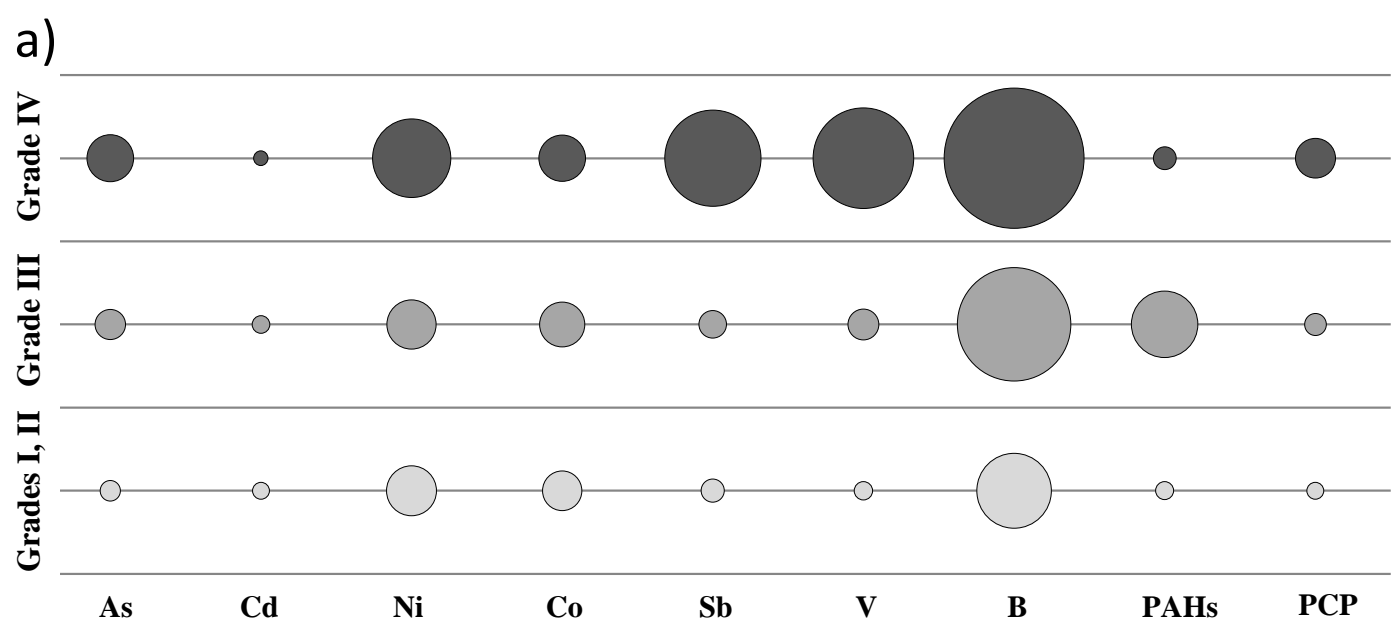

b)

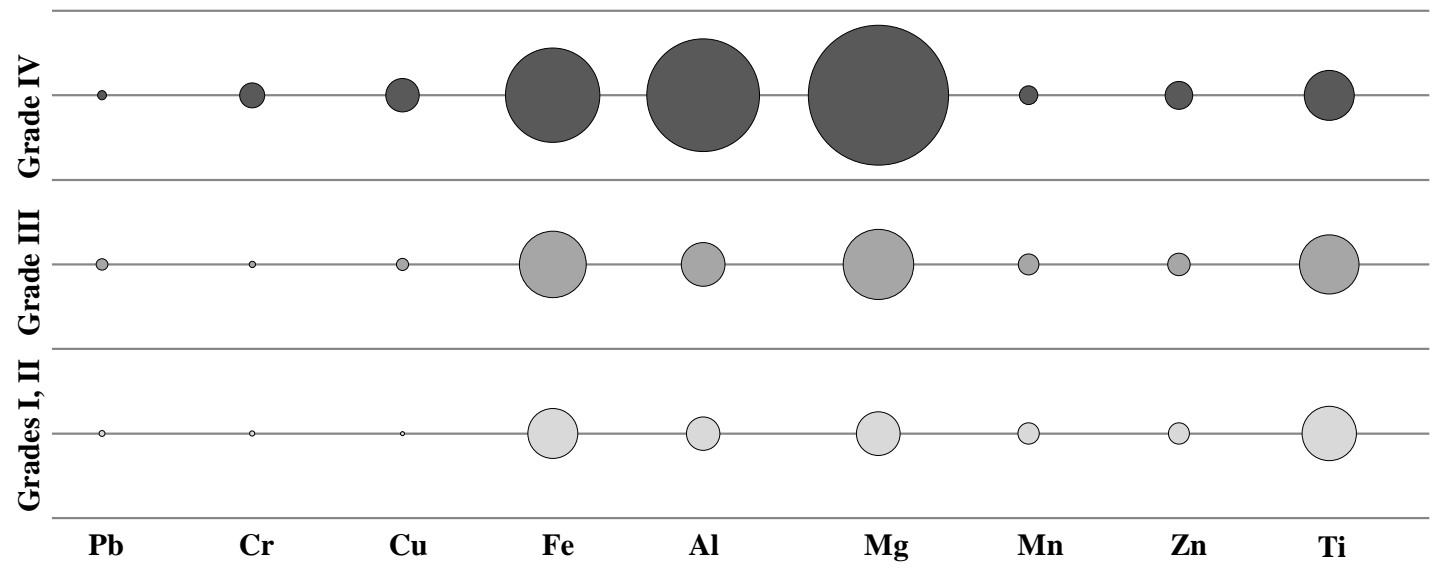

Figure 6. Concentration levels of selected inorganic and organic compounds in wood waste (WW) for quality grades I/II, quality grade III and quality grade IV. Due to their low concentration, and for the sake of readability, PCBs are excluded. The size of the bubbles is proportional to the mean concentration for all four quality grades (vertical). The areas of all bubbles within each subfigure are further scaled relative to the highest concentration in each subfigure (20 ppm in a) and $4628 \mathrm{ppm}$ in $\mathrm{b}$ ).

from torrefaction of particleboard 267 times higher than other wood feedstock, therefore calling for studies on the appropriate management of this class of wood waste.

Comparing the concentration levels found in this study with available scientific publications and databases revealed that our samples were cleaner than the wood waste intended for incineration addressed in other studies (see Figure M.1). This was the case for all contaminants apart from $\mathrm{Mg}$ and $\mathrm{Co}$. Significantly higher levels were observed in the literature for $\mathrm{As}, \mathrm{Cr}$ and $\mathrm{Zn}$ in wood waste for incineration. These comparisons should be used cautiously due 
to differences in methodology among studies, e.g. sampling activities, processing of samples, type of chemical analyses: also, the extent to which impurities are removed depend on the kind of sorting (manual or mechanical such as screening and sieving). Comparisons are shown here only as illustrative of the diverse order of magnitude that the composition of wood waste may assume depending on its treatment route. In selected market situations (e.g. shortage of raw materials), WW from quality Grade III could be included in the clean feedstock for recycling, provided sufficient dilution with clean feedstock and/or recycling in applications without risk to users or further spreading in the environment. In all cases, it is recommended that quality Grade IV materials are maintained separately, to avoid risk-cycling of contaminants. The fact that this study identified Grade IV materials in the wood waste fraction otherwise sent for recycling clearly indicates that the potential for quality improvement exists through improving collection procedures. Furthermore, this suggests that additional monitoring measures (information campaigns, assistance at recycling centres, etc.) could be implemented to minimise the presence of impregnated wood in WW for recycling: impregnated wood was already separately collected at the recycling centres involved in this study. With EU policies favouring cascading recycling of materials, multiple recycling loops involving the same waste materials may lead to the potential accumulation of chemicals in recycled products, if the contaminated materials are not controlled appropriately. Measures such as standardising wood waste classes according to contamination and material composition, labelling, monitoring and advanced separation technologies may potentially improve the quality - and hence the recoverability - of the material.

As discussed in the previous sections, some wood types generally had higher concentrations of chemical contaminants in the individual wood subcategories (types, all grades) than others (see Table N.1), namely 'Off cuts, or large wood chips (with fibreboard a and/or treated wood)' (O2, 12 chemicals), 'Other packaging (untreated, no fibreboard)' (P3, 7 chemicals), 'Old wood from demolition and rebuilding (with fibreboard and/or treated wood) - outdoor use' (C3, 7 chemicals), 'Furniture (with fibreboard and/or treated wood)' (F2, 9 chemicals), 'Impregnated wood' (M1, 11 chemicals) and 'Composite building materials from C\&D’ (M2, 13 chemicals). Not surprisingly, almost all of these subcategories (except for P3) fall into quality Grades III or IV, highlighting the fact that, if unsorted, the level of impurities in the recycled wood products may increase if included in the wood waste for recycling. Preferably, these 
more contaminated wood waste types should be collected and managed separately from the cleaner fractions.

With respect to recycling, focus should be placed on 'Off-cuts (untreated, no fibreboard)' (O1), 'Pallet (untreated, no fibreboard)' (P1), 'Wood from C\&D and rebuilding (untreated, no fibreboard) - indoor use' (C1) and 'Furniture (untreated, no fibreboard)' (F1), as these fractions contained the lowest levels for all chemicals. Within this study the role of impurities and quality of wood waste has been discussed mainly with respect to a cleaner particleboard production, as this material application is capable to absorb a large share of post-consumer wood waste. However, some qualities of wood waste can also be re-used in building applications. While recycling as building construction material is certainly beneficial, some parameters such as the dimension and structural properties of the wood waste may limit the usable feedstock. Nevertheless, the abovementioned considerations on the categories and type of wood to prioritize are applicable also to building material applications. A harmonised classification of wood waste, and the implementation of quality criteria across all sectors, may be needed to ensure clean material flows for wood recycling and at the same time offer a basis for recycling facilities to reject unwanted fractions prior to reprocessing.

\section{Conclusions}

Eight tonnes of wood waste (WW) collected for recycling were sampled at three different recycling centres in Denmark. The wood waste was separated manually into 34 fractions and analysed with respect to different material classes (Off-cuts, Packaging, Construction \& demolition - C\&D, Furniture and Misplacements), quality grade (I to IV) as well as content of physical and chemical impurities. The C\&D sector represented the largest source of WW, followed by Furniture, Packaging and Off-cuts. Material impurities accounted for $59 \%, 12 \%$ and $50 \%$ of the total WW collected for recycling at each of the three recycling centres. This clearly indicates that considerable potential for improving wood waste quality exists. The concentration levels of $\mathrm{As}, \mathrm{Cd}, \mathrm{Cr}$, $\mathrm{Cu}, \mathrm{Pb}, \mathrm{Al}, \mathrm{Mg}, \mathrm{Mn}, \mathrm{Ni}, \mathrm{Zn}, \mathrm{Fe}, \mathrm{Co}, \mathrm{Sb}$, Ti, V, B, PCP, PAHs, phenols and PCBs varied between wood waste classes, generally with higher levels for Low-quality WW (Grade III) and hazardous wood waste (Grade IV). To ensure the lowest overall level of contaminants, emphasis should be placed on recycling fractions such as 'Off-cuts', 'Pallets', 'Wood from C\&D and rebuilding (untreated, no fibreboard) - indoor use' and 'Furniture', while fractions containing fibreboard, treatments and/or composite materials from 
$\mathrm{C} \& \mathrm{D}$ should be minimised in recycled material. While existing limit standards set by particleboard producers were met by all WW samples in this study, the results clearly indicated that technological, operational and regulatory improvements associated with the collection, sorting, management and recycling of WW from recycling centres may decrease the levels of material and chemical impurities in products based on waste wood. Moreover, WW collected for recycling should not be regarded as a single material flow but rather as the sum of a wide range of individual fractions whose properties and contamination level depend on the type and source of the materials. To enhance further clean wood waste recycling and circular economy solutions involving wood, this study demonstrates that specific knowledge of wood waste quality is critical.

\section{Acknowledgements}

The Danish Environmental Protection Agency is highly appreciated for funding this study. Furthermore, the authors would like to thank Econet A/S for giving access to the wood waste sampling. The authors are also grateful to M. K. Erikssen and M. E. Edjabou (Technical University of Denmark) for useful comments on the manuscript.

\section{Funding}

This work was supported by the Danish Environmental Protection Agency (Miljøstyrelsen).

\section{Appendices}

Supplementary data files related to this article can be found at ... 


\section{References}

Abb, M., Breuer, J. V, Zeitz, C., Lorenz, W., 2010. Chemosphere Analysis of pesticides and PCBs in waste wood and house dust. Chemosphere 81, 488-493. https://doi.org/10.1016/j.chemosphere.2010.07.042

Altholz V (2012) Verordnung über Anforderungen an die Verwertung und Beseitigung von Altholz (Altholzverordnung - AltholzV). The German waste wood ordinance.

Andersson, M., Ottesen, R.T., Volden, T., 2004. Building materials as a source of PCB pollution in Bergen, Norway. Sci. Total Environ. 325, 139-144. https://doi.org/10.1016/j.scitotenv.2003.11.014

ARC (Amager Resource Centre). 2013. Driftshåndbog for genbrugspladser - 3.0 Sorteringsvejledning. Fraktion 35: Træ til genanvendelse. (in Danish)

Arm, M., Wik, O., Engelsen, C.J., Erlandsson, M., Hjelmar, O., Wahlström, M., 2016. How Does the European Recovery Target for Construction \& Demolition Waste Affect Resource Management? Waste and Biomass Valorisation 1-14. https://doi.org/10.1007/s12649-016$9661-7$

Astrup, T., Riber, C., Pedersen, A.J., 2011. Incinerator performance : effects of changes in waste input and furnace operation on air emissions and residues. https://doi.org/10.1177/0734242X11419893

Augustsson, A., Sörme, L., Karlsson, A., Amneklev, J., 2016. Persistent Hazardous Waste and the Quest Toward a Circular Economy: The Example of Arsenic in Chromated Copper Arsenate-Treated Wood. J. Ind. Ecol. 0, 1-11. https://doi.org/10.1111/jiec.12516

Bergeron, F. C. 2014. Assessment of the coherence of the Swiss waste wood management. Resour. Conserv. Recycl. 91, 62-70.

Boldrin, A., Christensen, T.H., 2010. Seasonal generation and composition of garden waste in Aarhus (Denmark). Waste Manag. 30, 551-557. https://doi.org/10.1016/j.wasman.2009.11.031

Bundt, M., Krauss, M., Blaser, P., Wilcke, W., 2001. Forest Fertilisation with Wood Ash: Effect on the Distribution and Storage of Polycyclic Aromatic Hydrocarbons (PAHs) and Polychlorinated Biphenyls (PCBs). Acta Geodyn. Geomater. 9, 1296-1304.

Butera, S., Christensen, T.H., Astrup, T.F., 2014. Composition and leaching of construction and demolition waste: Inorganic elements and organic compounds. J. Hazard. Mater. 276, 302-311. https://doi.org/10.1016/j.jhazmat.2014.05.033

Czarnecki, R.; Dziurka, D. and Mirski, R. 2005. The use of recycled boards as the substitute for particles in the centre layer of particleboards. Proceedings for COST E31 Conference, Bordeaux, 2005, p. 304.

Defra (Department for Environment Food and Rural Affairs). 2012. Wood waste : A short review of recent research. Downloaded 
https://www.gov.uk/government/uploads/system/uploads/attachment_data/file/82571/con sult-wood-waste-researchreview-20120731.pdf Accessed 21 July 2016

Demirbas, A., 2005. Potential applications of renewable energy sources, biomass combustion problems in boiler power systems and combustion related environmental issues. Prog. Energy Combust. Sci. 31, 171-192. https://doi.org/10.1016/j.pecs.2005.02.002

Dodoo, A., Gustavsson, L., Sathre, R., 2014. Recycling of Lumber, Handbook of Recycling: State-of-the-art for Practitioners, Analysts, and Scientists. Elsevier Inc. https://doi.org/10.1016/B978-0-12-396459-5.00011-8

Econet A/S. (2016). Rent træ fra Assens Forsynings genbrugspladser Indholdsfortegnelse Bilag, 1-24. Retrieved from https://econetdk.sharepoint.com/Deltedokumenter/Projekter 500-599/595Assens -RenttræfraGBP/Rapport/2016-04-01 rapport.docx 24 (in Danish)

Edo, M., Björn, E., Persson, P.E., Jansson, S., 2015. Assessment of chemical and material contamination in waste wood fuels - A case study ranging over nine years. Waste Manag. 49, 311-319. https://doi.org/10.1016/j.wasman.2015.11.048

EPA (Environmental Protection Agency). 1980. Application Note EPA methods 3015A, 3051A and 3052. Methods 3015a, 3051a and 3052, 1-3.

EPF (European Panel Federation). 2014. EPF standard for delivery conditions of recycled wood. Available at: http://europanels.org/publications/epf-standards

EPRS (European Parliamentary Research Service). 2015. Understanding waste streams Treatment of specific waste. Briefing.

Erlandsson, M., Almemark, M., 2009. Background data and assumptions made for an LCA on creosote poles - Working report. Stockholm.

European Commission. 1998. Directive 98/8/EC of the European Parliament and of the Council of 16 February 1998 concerning the placing of biocidal products on the market. Available at: http://eur-lex.europa.eu/legal-content/EN/TXT/?uri=celex\%3A31998L0008

European Commission. 2001. Directive 2001/90/EC of 26 October 2001 adapting to technical progress for the seventh time Annex I to Council Directive 76/769/EEC on the approximation of the laws, regulations and administrative provisions of the Member States relating to restrictions on the marketing and use of certain dangerous substances and preparations (creosote). Available at: http://eur-lex.europa.eu/legalcontent/EN/TXT/HTML/?uri=CELEX:32001L0090\&from=IT

European Commission. 2003. Directive 2003/2/EC of 6 January 2003 relating to restrictions on the marketing and use of arsenic (tenth adaptation to technical progress to Council Directive 76/769/EEC). Available at: http://eur-lex.europa.eu/eli/dir/2003/2/oj

European Commission. 2006. Regulation (EC) No 1907/2006 of the European Parliament and of the Council of 18 December 2006 concerning the Registration, Evaluation, Authorisation and Restriction of Chemicals (REACH), establishing a European Chemicals Agency, amending Directive 1999/45/EC and repealing Council Regulation (EEC) No 793/93 and Commission Regulation (EC) No 1488/94 as well as Council Directive 
76/769/EEC and Commission Directives 91/155/EEC, 93/67/EEC, 93/105/EC and 2000/21/EC. Available at: http://eur-lex.europa.eu/legalcontent/EN/TXT/?uri=CELEX\%3A02006R1907-20140410

European Commission, 2015. Construction and Demolition Waste management in Germany. Available http://ec.europa.eu/environment/waste/studies/deliverables/CDW_Germany_Factsheet_Fi nal.pdf

European Commission. 2018. Measuring progress toward circular economy in the European Union - Key indicators for a monitoring framework. Commission staff working document accompanying the document "Communication from the Commission to the European Parliament, the Council, the European Economic and Social Committee and the Committee of the Regions on a monitoring framework for a circular economy". Available at: http://ec.europa.eu/environment/circular-economy/pdf/monitoring-framework.pdf

FAO/UNECE (Food and Agriculture Organization/United Nations Economic Commission for Europe). 2016. Forest Products. Annual market overview 2015-2016. Geneva, October 2016. ISBN: 978-92-1-117115-0

Fjelsted, L., Christensen, T.H., 2007. Household hazardous waste: composition of paint waste. Waste Manag. Res. 25, 502-509. https://doi.org/10.1177/0734242X07082956

Frighetto Ferrarini, S., Souza dos Santos, H., Gampert Miranda, L., Nunes Azevedo, C.M., Maia, S.M., Pires, M., 2016. Decontamination of CCA-treated eucalyptus wood waste by acid leaching. Waste Manag. 49, 253-262. https://doi.org/10.1016/j.wasman.2016.01.031

Gy, P., 1998. Sampling for Analytical Purposes. John Wiley \& Sons Ltd., Chichester, UK.

Helsen, L., Van Den Bulck, E., Hery, J.S., 1998. Total recycling of CCA treated wood waste by low-temperature pyrolysis. Waste Manag. 18, 571-578. https://doi.org/10.1016/S0956053X(98)00148-2

Herrick, R.F., McClean, M.D., Meeker, J.D., Baxter, L.K., Weymouth, G.A., 2004. An unrecognized source of PCB contamination in schools and other buildings. Environ. Health Perspect. 112, 1051-1053. https://doi.org/10.1289/ehp.6912

Humbert-Droz, A. Coutrot, D. 2016. Contribution to the circular economy: recycling furniture, inclusion in the virtuous cycle of wood. 10th European Wood-based Panel Symposium, Hamburg.

Höglmeier, K., Weber-Blaschke, G., Richter, K., 2014. Utilization of recovered wood in cascades versus utilization of primary wood-a comparison with life cycle assessment using system expansion. Int. J. Life Cycle Assess. 1755-1766. https://doi.org/10.1007/s11367014-0774-6

IEA Bioenergy Task 32, http://task32.ieabioenergy.com/ (last accessed 30.02.2016)

International Union of Railways. 2003. SUWOS Sustainable Wooden railway Sleepers. Available at: www.traskydd.com/1.0.2.0/165/download_802.php 
IRCOW (2014): Innovative strategies for high-grade material recovery from construction and demolition waste - Final Summary Brochure. Available at: http://www.ircow.eu/media/downloads/IRCOW_final_brochure.pdf

Janin, A., Blais, J.F., Drogui, P., 2009. Optimization of a chemical leaching process for decontamination of CCA-treated wood. J. Hazard. Mater. 169, 136-145. https://doi.org/10.1016/j.jhazmat.2009.03.064

Jartun, M., Ottesen, R.T., Steinnes, E., Volden, T., 2009a. Painted surfaces - Important sources of polychlorinated biphenyls (PCBs) contamination to the urban and marine environment. Environ. Pollut. 157, 295-302. https://doi.org/10.1016/j.envpol.2008.06.036

Jartun, M., Ottesen, R.T., Volden, T., Lundkvist, Q., 2009b. Local sources of polychlorinated biphenyls (PCB) in Russian and Norwegian settlements on Spitsbergen Island, Norway. J. Toxicol. Environ. Heal. - Part A Curr. Issues 72, 284-294. https://doi.org/10.1080/15287390802539426

Johansson, I., Van Bavel, B., 2003a. Polycyclic aromatic hydrocarbons in weathered bottom ash from incineration of municipal solid waste. Chemosphere 53, 123-128. https://doi.org/10.1016/S0045-6535(03)00299-6

Johansson, I., Van Bavel, B., 2003b. Levels and patterns of polycyclic aromatic hydrocarbons in incineration ashes. Sci. Total Environ. 311, 221-231. https://doi.org/10.1016/S00489697(03)00168-2

Jungmeier, G., Werner, F., Jarnehammar, A., Hohenthal, C., Richter, K., 2002. Allocation in LCA of Wood-based Products: Experiences of Cost Action E9, Part I. Methodology. Int. J. 7, 369-375. http://dx.doi.org/10.1065/Ica2002.08.091.1

Jungmeier, G., Werner, F., Jarnehammar, A., Hohenthal, C., Richter, K., 2002. Allocation in LCA of Wood-based Products: Experiences of Cost Action E9, Part II. Examples. Int. J. Life Cycle Assess. 7, 369-375. https://doi.org/10.1007/BF02978890

Krook, J., Mårtensson, A., Eklund, M., 2004. Metal contamination in recovered waste wood used as energy source in Sweden. Resour. Conserv. Recycl. 41, 1-14. https://doi.org/10.1016/S0921-3449(03)00100-9

Krook, J., Mårtensson, A., Eklund, M., 2006. Sources of heavy metal contamination in Swedish wood waste used for combustion. Waste Manag. 26, 158-166. https://doi.org/10.1016/j.wasman.2005.07.017

Li, Y., Li, B., Du, F., Wang, Y., Pan, L., Chen, D., 2016. Microwave-assisted hydrothermal liquefaction of lignin for the preparation of phenolic formaldehyde adhesive. J. Appl. Polym. Sci. 44510, 1-8. https://doi.org/10.1002/app.44510

Löser, C., Ulbricht, H., Hoffmann, P., Seidel, H., 1999. Composting of Wood Containing Polycyclic Aromatic Hydrocarbons ( PAHs ) Composting of Wood Containing 2397. https://doi.org/10.1080/1065657X.1999.10701971 
Mantau, U., Saal, U., Prins, K., Steierer, F., Lindner, M., Verkerk, H., Eggers, J., Leek, N., Oldenburger, J., Asikainen, A., Anttila, P., 2010. EUwood - Real potential for changes in growth and use of EU forests. Final report. EUwood 106p.

Meinander, M., Mroueh, U.-M., Bacher, J., Laine-Ylijoki, J., Wahlström, M., Jermakka, J., Teirasvuo, N., Kuosa, H., Törn, M., Laaksonen, J., Heiskanen, J., Kaila, J., Vanhanen, H., Dahlbo, H., Saramäki, K., Jouttijärvi, T., Mattila, T., Retkin, R., Suoheimo, P., Lähtinen, K., Sironen, S., Sorvari, J., Myllymaa, T., Havukainen, J., Horttanainen, M., Luoranen, M., 2012. Directions of future developments in waste recycling. Downloaded at: http://www.vtt.fi/inf/pdf/technology/2012/T60.pdf

Mesch, K., 2010. Heat stabilizers. Encyclopedia of Polymer Science and Technology.

Mueller, J.G., Chapman, P.J., Pritchard, P.H., 1989. Creosote-contaminated sites. Their potential for bioremediation. Environ. Sci. Technol. 23, 1197-1201. https://doi.org/10.1021/es00068a003

Parham, R. and Gray. (1984). Formation and structure of wood. In R. R., The chemistry of solid wood (p. 588). Washington DC: Advances in chemistry series.

Phyllis2. 2016. ECN Phyllis classification and database. https://www.ecn.nl/phyllis2/Browse/Standard/ECN-Phyllis\#wood (last accessed 27.02.16)

Ravindra, K., Sokhi, R., 2008. Atmospheric polycyclic aromatic hydrocarbons: Source attribution, emission factors and regulation. Atmos. Environ. 42, 2895-2921. https://doi.org/10.1016/j.atmosenv.2007.12.010

Reichel, A., De Schoenmakere, M., Gillabel, J., Martin, J., \& Hoogeveen, Y. 2016. Circular Economy in Europe Developing the Knowledge Base. http://doi.org/10.2800/51444

Robson, M., Melymuk, L., Csiszar, S.A., Giang, A., Diamond, M.L., Helm, P.A., 2010. Continuing sources of PCBs: The significance of building sealants. Environ. Int. 36, 506513. https://doi.org/10.1016/j.envint.2010.03.009

Rudel, R.A., Seryak, L.M., Brody, J.G., 2008. PCB-containing wood floor finish is a likely source of elevated PCBs in residents' blood, household air and dust: A case study of exposure. Environ. Heal. A Glob. Access Sci. Source 7, 1-8. https://doi.org/10.1186/1476069X-7-2

Sarenbo, S., 2009. Wood ash dilemma-reduced quality due to poor combustion performance. Biomass and Bioenergy 33, 1212-1220. https://doi.org/10.1016/j.biombioe.2009.05.007

Sathre, R., Gustavsson, L., 2006. Energy and carbon balances of wood cascade chains. Resour. Conserv. Recycl. 47, 332-355. https://doi.org/10.1016/j.resconrec.2005.12.008

Tafur-Marinos, J. A., Ginepro, M., Pastero, L., \& Zelano, V. (2016). Digestion Procedures for the Elemental Analysis of Wood by Inductively Coupled Plasma Optical Emission Spectrometry. Anal. Lett. 49(11), 1722-1733. http://doi.org/10.1080/00032719.2015.1120309 
The Ecocycle Council for the Building Sector., 2003. Byggsektorns Miljø Program (The Environmental Program for the Swedish Building Sector). The Ecocycle Council for the Building Sector, Stockholm (in Swedish).

Trada Technology and Enviros Consulting Ltd. 2005. Options and Risk Assessment for Treated Wood Waste. The Waste \& Resources Action Programme (WRAP), Banbury (Oxon), June 2005. ISBN No: 1-84405-177-3

Ummey, N. Rivers, S. 2003. Conservation of Furniture. Butterworth-Heinemann Series in Conservation and Museology NV - Plates : Ill. (Some Col.); 26 Cm, xxxiii, 803.

UNECE (United Nations Economic Commission for Europe). (2010). The 1998 Protocol on Persistent Organic Pollutants, Including the Amendments Adopted by the Parties on 18 December 2009. ECE/EB.AIR/104.

Vick, C. B., Geimer, R.L. and Wood, J.E. 1996. Flakeboards from Recycled CCA-Treated Southern Pine Lumber. Forest Prod J 46 (11/12) pp. 89 - 91

UNEP (2009). Stockholm Convention on Persistent Organic Pollutants, as amended in 2009 - text and annexes. www.pops.int

USEPA (United States Environmental Protection Agency). 1985. Technical Support Document for Water Quality Based Toxics Control, EPA/440/485032, Washington, DC, USA.

US EPA (United States Environmental Protection Agency). 1992. Contaminants and remedial options at wood preserving sites

Vis M., Mantau U., Allen B. (Eds.) 2016. Study on the optimized cascading use of wood. No 394/PP/ENT/RCH/14/7689. Final report. Brussel 2016. 337 pages

Värmeforsk, 2012. Report 1234: Bränslehandboken 2012 (The Fuel Handbook 2012). ISSN 1653-1248, pp. 442.

Wiebesiek, T. 2016. Boosting raw panel inspection with statistical classification. 10th European Wood-based Panel Symposium, Hamburg.

Wilson, J.B., 2009. CORRIM: Phase II Final Report Module H Resins: A Life-Cycle Inventory of Manufacturing Resins Used in the Wood Composites Industry.

Winder, G.M., Bobar, A., 2016. Responses to stimulate substitution and cascade use of wood within a wood use system: Experience from Bavaria, Germany. Appl. Geogr. 1-10. https://doi.org/10.1016/j.apgeog.2016.09.003

Wollf, M. 2016. European Wood-based Panel Symposium - Opening Speech, 10th European Wood-based Panel Symposium, Hamburg.

WRAP (Waste and Resources Action Programme). 2012a. PAS111:2012 Specification for the requirements and test methods for processing waste wood, British Standard Institution. ISBN: 978058069643 5, 2012

WRAP (Waste and Resources Action Programme). 2012b. The busines s case for wood waste collection hubs. Downloaded at: www.wrap.org.uk/wood 
